\title{
Penerapan Fuzzy Logic Control Untuk Sistem Pengaturan Kelembaban Udara Pada Greenhouse
}

\author{
Kharis Sugiarto $^{1}$, Supriatna Adhisuwignjo ${ }^{2}$, Denda Dewatama ${ }^{3}$ \\ ${ }^{1}$ Fakultas Teknik, Politeknik Ilmu Pelayaran Balikpapan, Indonesia \\ ${ }^{2,3}$ Fakultas Teknik, Politeknik Negeri Malang, Indonesia \\ kharissugiarto7@gmail.com¹ ${ }^{1}$, supriatna@polinema.ac.id ${ }^{2}$,denda.dewatama@polinema.ac.id ${ }^{3}$
}

\begin{abstract}
Abstrak
Kelembaban udara pada greenhouse khususnya selada keriting merupakan hal yang penting. Hal ini penting karena menanam selada keriting dengan kelembaban kurang dapat menyebabkan kematian. Dengan adanya masalah ini diperlukan sistem kontrol kelembaban udara. Aplikasi dari fuzzy logic control diharapkan untuk memecahkan masalah regulasi kelembaban udara pada greenhouse. Sensor yang digunakan adalah sensor DHT11. Fuzzy logic yang diterapkan memiliki 25 aturan, yang diperoleh dari 5 fungsi keanggotaan error dan 5 fungsi keanggotaan deltaerror. Penelitian ini menggunakan sistem inferensi fuzzy dengan metode mamdani untuk kontrol kelembaban udara dalam greenhouse. Pada aplikasi kontrol fuzzy untuk mencapai set-point kelembaban dari 60\% ke kondisi $79 \%$, diperoleh nilai parameter transient yaitu waktu tunak (ts) 570 detik, waktu naik (tr) 485 detik, waktu tunda (td) 60 detik, error steady state yaitu 0,7\% dan tanpa overshoot. Pada aplikasi kontrol fuzzy untuk mencapai setpoint dari kelembaban udara $60 \%$ RH menjadi $79 \%$ RH membutuhkan 600 detik.
\end{abstract}

Kata Kunci : DHT11, Fuzzy Logic Controller, Greenhouse, Kelembaban udara, Selada keriting

\begin{abstract}
Air humidity in greenhouse, especially the sativa L. lettuce is important. This is important because planting sativa L. lettuce with less humidity can cause death. Given these problems required humidity control system. Application of fuzzy logic control is expected to solve the problem of regulation of humidity in the greenhouse. The sensor used is a DHT11 sensor. Fuzzy logic rules are applied has 25, which is obtained from the membership functions 5 errors and 5 membership functions deltaerror. This study uses fuzzy inference system with mamdani method to control humidity in the greenhouse. On the application of fuzzy control to achieve setpoint of $60 \%$ RH to $79 \%$ RH humidity conditions, namely transient parameters obtained (ts) 570 seconds, (tr) 485 seconds, (td) 60 seconds, the steady state error 0.7\% and without overshoot. On the application of fuzzy control to achieve setpoint requires 600 seconds.
\end{abstract}

Keywords : DHT11, Fuzzy Logic Controller, Greenhouse, Humidity, sativa L. lettuce

\section{PENDAHULUAN}

Pengaturan kelembaban udara pada greenhouse khususnya selada keriting merupakan hal yang penting. Hal ini menjadi penting disebabkan penanaman selada keriting dengan kelembaban udara yang kurang dapat mengakibatkan gangguan pada pertumbuhan serta dapat menyebabkan kematian. Dengan adanya masalah ini diperlukan sistem kontrol kelembaban udara. Untuk mendeteksi keadaan kelembaban udara pada greenhouse mengunakan sensor DHT11. Pada sistem kontrol kelembaban ini menggunaan fuzzy logic controller. Fuzzy logic controller mulai dikenalkan sekitar tahun 1960-an[1]. Konsep ini menjadi pilihan karena secara controller mudah dimengerti, metode fuzzy logic ini dapat bekerja pada situasi yang memiliki variasi parameter dan struktur dari plant dengan tingkat ketidak pastian besar[2]. Fuzzy logic control banyak diterapkan dalam berbagai aplikasi[2]-[6]. Fuzzy logic ini memiliki beberapa pengembang metode diantaranya metode mamdani yang diperkenalkan oleh Ibrahim mamdani. Metode mamdani ini sering disebut dengan metode min-max[7]. Pada penelitian ini menggunakan inferensi fuzzy dengan metode mamdani untuk menyelesaikan masalah pengaturan kelembaban pada green house.

\section{METODOLOGI}

\subsection{Greenhouse}

Greenhouse merupakan sebuah bagunan yang dibuat untuk pelindung berbagai bentuk media tanam dan tanaman[8]. Pada dewasa ini greenhouse bukan hal yang istimewa akan tetapi hal yang bisa dibuat oleh setiap pengembang pertanian. Greenhouse bisa 
dibuat dari berbagai bentuk bahan baik dari kayu, almunium, sampai besi. Greenhouse bukan lagi bagunan yang dibentuk dari kaca, akan tetapi banyak jenis yang intinya bahan tersebut dapat digunakan untuk melindungi dari gelombang ultraviolet yang berlebih. Penelitian ini mengunakan bahan plastik untuk membentuk greenhouse.

Greenhouse sendiri dipengaruhi beberapa faktor yang rentan dan harus dijaga diantaranya suhu ruang, intensitas cahaya, serta kelembaban udara. Pada penelitian ini membahas sistem kontrol kelembaban udara dalam greenhouse [9].

\subsection{Selada Keriting}

Selada keriting ialah sayuran semusim yang banyak di budidayakan oleh masyarakat. Selada keriting memiliki daun yang tersusun tidak beraturan dan batang pendek tertutup oleh daun, seperti ditunjukan dalam gambar 1 . Selada tumbuh dengan baik pada kisaran kelembaban 76\%-80\% RH[10]. Pada penelitian mengunakan sampel kelembaban ke31 dengan setpoint dari kelembaban $60 \%$ RH menjadi $79 \% \mathrm{RH}$.

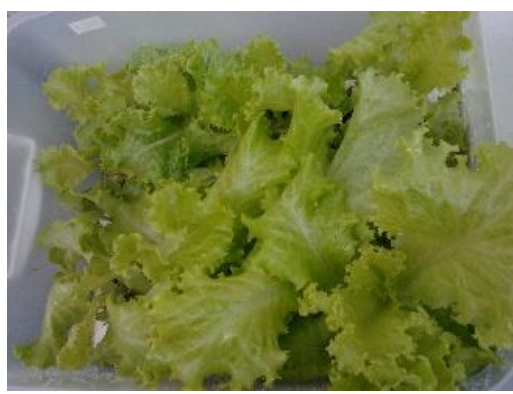

Gambar 1 Selada Keriting

\subsection{Sensor Kelembaban Udara}

Sensor kelembaban udara yang digunakan pada sistem kontrol ini adalah DHT11, seperti ditunjukan pada gambar 2. Sensor kelembaban udara DHT11 merupakan komponen elektronika yang berfungsi untuk mendeteksi kelembaban udara serta suhu dan mengubah pembacaan sensor menjadi sinyal digital. Sensor DHT11 memiliki fitur kalibrasi yang cukup akurat dari sensor kelembaban yang lain. Untuk tegangan input membutuhkan 5 volt dc, temperatur yang dapat dibaca 0 sampai dengan 50 derajat celcius dengan kesalahan plus minus 2 derajat celcius, untuk pembacaan kelembaban sensor ini mampu membaca dari 20 sampai dengan $90 \% \mathrm{RH}$ dengan kesalahan plus minus 5\% RH error[11].

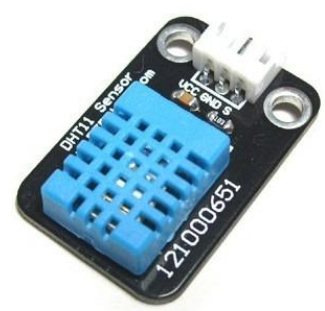

Gambar 2 Sensor kelembaban udara DHT11

\subsection{Fuzzy Logic}

Sebelum adanya teori fuzzy logic, dikenal sebuat Crisp logic yang memiliki nilai salah atau benar secara tegas. Sedang fuzzy logic merupakan sebuah logika yang memiliki nilai ketidak pastian antar salah dan benar. Fuzzy logic sendiri dikemukakan pada tahun 1960 oleh Lotfi Zadeh. Dalam teori fuzzy suatu nilai bisa bernilai salah atau benar dalam waktu yang bersamaan, adapun besar kesalahan dan kebenaran tergantung pada bobot keanggotaan yang dimilikinya[1]

Metode mamdani diperkenalkan oleh Ebrahim mamdani (1975). Metode mamdani sering disebut dengan metode min-max. Menurut metode mamdani untuk mendapatkan output, diperlukan empat tahap:

1) Tahap pertama menentukan himpunan fuzzy. Pada langkah pertama proses fuzzifikasi yaitu menentukan variable fuzzy dan himpunan fuzzy. Selanjutnya menentukan degree of match antara data masukan fuzzy dan himpunan fuzzy-nya[12].

2) Tahap kedua fungsi implikasi. Pada metode mamdani fungsi implikasi yang digunakan yaitu min. Hasil implikasi dari setiap aturan kemudian digabungkan untuk memperoleh infrensi fuzzy-nya[13].

3) Tahap ketiga membentuk Komposisi aturan. Saat sistem terdiri dari beberapa aturan, maka infrensi diperoleh dari kumpulan dan korelasi antar aturan. Adapun metode yang digunakan infrensi sistem fuzzy, fuzzy, yaitu: max, additive dan probabilistic OR[12].

4) Tahapan keempat adalah defuzzy. Input proses defuzzifikasi adalah himpunan fuzzy yang diperoleh dari komposisi aturan fuzzy, sedang output yang diperoleh merupakan bilangan pada domain himpunan fuzzy[12].

\subsection{Konfigurasi Sistem}

Secara umum sistem pengaturan kelembaban udara dalam greenhouse terdiri dari beberapa bagian yang saling berhubungan. Adapun blok diagram 
secara umum sistem pengaturan kelembaban udara dalam greenhouse dapat ditunjukan pada Gambar 3.

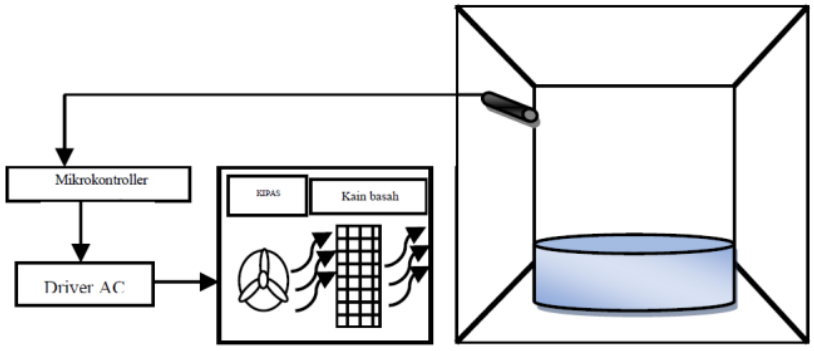

Gambar 3 Blok Diagram kontrol kelembaban udara

\subsection{Menentukan Variabel Input dan Output}

Dalam pembentukan kontrol fuzzy langkah awal yang harus dilakukan adalah menentukan variable input dan variable output. Pada sistem kontrol Variable input yang digunakan yaitu kelembaban udara dalam greenhouse dan variable output berupa kipas angin (fan $A C)$.

\subsection{Membentuk Himpunan Fuzzy}

Himpunan fuzzy merupakan keadaan tertentu dalam suatu variable fuzzy. Variable liguistik yang digunakan adalah sebagai berikut,

\section{1) Variable Input}

Semua variable input membentuk himpunan fuzzy dan semesta pembicaraan sebagai berikut,

- Variable input kelembaban udara $=\{$ Negatif Besar, Negatif Kecil, Zero, Positif Kecil, dan Positif Besar\}.

2) Variable Output

Semua variable output membentuk himpunan fuzzy dan semesta pembicaraan sebagai berikut,

- Variable output kipas angin $=\{$ Zero, Low, Medium, High, dan Very High\}.

\subsection{Membentuk Fungsi Keanggotaan Input Fuzzy}

Fungsi keanggotaan masukan yang terbentuk dari error dan deltaerror terdiri atas lima label (NB), (NK), (Z), (PK), dan (PB). Error adalah nilai setpoint dikurangi dengan nilai yang diinginkan, sedangkan deltaerror diperoleh dari nilai error sekarang dikurangi nilai error sebelumnya. Data masukan dari fungsi keanggotaan didapat dari nilai keluaran sensor. Dalam penelitian fungsi keanggotaan masukan error dan masukan deltaerror diambil dari sampel ke-31. Fungsi keangotaan error yang dimaksud adalah seperti ditunjukan Gambar 4 dan fungsi keanggotaan deltaerror ditunjukan Gambar 5.

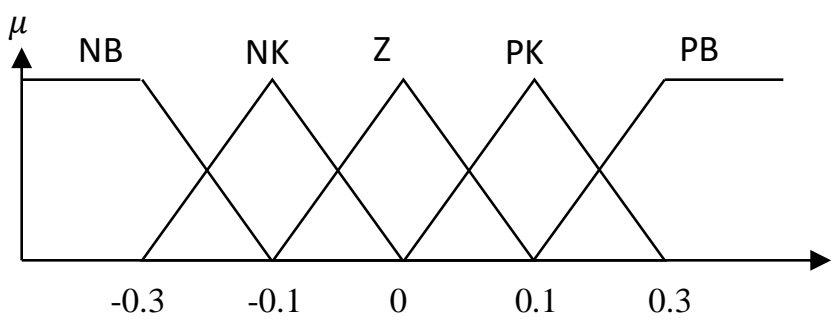

Gambar 4 Fungsi keanggotaan masukan error saat setpoint $<70 \%$

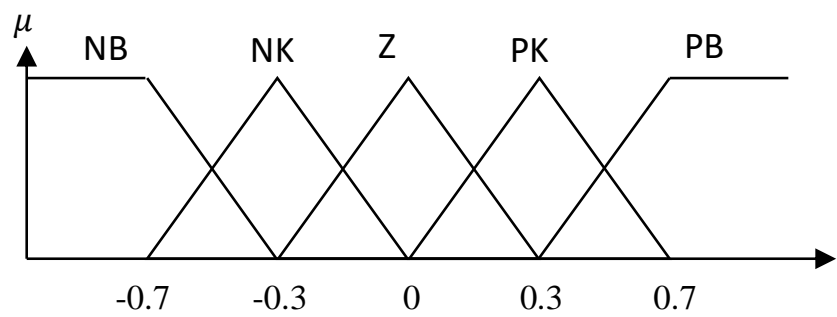

Gambar 5 Fungsi keanggotaan masukan deltaerror saat setpoint $<70 \%$

\subsection{Membentuk Fungsi Keanggotaan Output Fuzzy}

Fungsi keanggotaan keluaran yang terdiri atas lima label yang diubah dari variable liguistik kedalam variable crisp. Variable output yang dimaksudkan ditunjukan pada Tabel 1.

Tabel 1 Fungsi keanggotaan sistem

\begin{tabular}{|c|c|c|}
\hline $\begin{array}{c}\text { Sudut Picu } \\
\text { Phasa }\end{array}$ & $\begin{array}{c}\text { Label } \\
\text { Output }\end{array}$ & $\begin{array}{c}\text { Label } \\
\text { konversi Output }\end{array}$ \\
\hline 0 & Very High & Negatif Besar \\
\hline 30 & High & Negatif Kecil \\
\hline 90 & Medium & Zero \\
\hline 120 & Low & Positif Kecil \\
\hline 165 & Very High & Positif Besar \\
\hline
\end{tabular}

Fungsi keanggotaan untuk kipas dengan sudut penyalaan 0 sampai 165 derajat. Fungsi keanggotaan output dinyatakan Negatif Besar (NB), Negatif Kecil (NK), Zero (Z), Positif Kecil (PK), dan Positif Besar (PB) seperti yang ditunjukan pada Gambar 6.

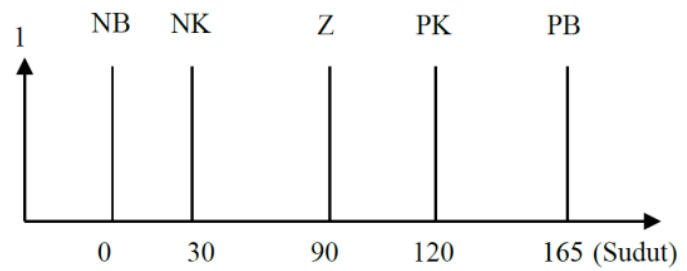

Gambar 6 Fungsi keanggotaan output sudut phasa 
Berdasarkan proses konversi ke program mikrokontroler adapun nilai untuk membentuk sudut penyalaan kipas kedalam fungsi waktu seperti ditunjukan pada Tabel 2.

Tabel 2 Fungsi keanggotaan dalam fungsi waktu

\begin{tabular}{|c|c|c|}
\hline $\begin{array}{c}\text { Label } \\
\text { Output }\end{array}$ & $\begin{array}{c}\text { Sudut Picu } \\
\text { Phasa }\end{array}$ & $\begin{array}{c}\text { Konversi } \\
\text { Dalam Fungsi } \\
\text { Waktu (ms) }\end{array}$ \\
\hline Negatif Besar & 0 & 0 \\
\hline Negatif Kecil & 30 & 1.6 \\
\hline Zero & 90 & 5 \\
\hline Positif Kecil & 120 & 6 \\
\hline Positif Besar & 165 & 9 \\
\hline
\end{tabular}

\subsection{Membentuk Aturan-Aturan Fuzzy}

Aturan fuzzy digunakan sebagai penentu keluaran dari fuzzifikasi yang akan diolah dalam proses defuzzifikasi, dengan jumlah aturan 25 macam. Aturan tersebut terbentuk dari lima fungsi keanggotaan error dan lima fungsi keanggotaan deltaerror. Aturan-aturan fuzzy yang terbentuk adalah seperti ditunjukan Tabel 3.

Tabel 3 Aturan-aturan Fuzzy

\begin{tabular}{|c|c|c|c|c|c|}
\hline de & NB & NK & $Z$ & PK & PB \\
\hline NB & NB & NB & NB & NK & $Z$ \\
\hline NK & NB & NK & NK & $Z$ & PB \\
\hline$Z$ & NB & NK & $Z$ & PK & PB \\
\hline PK & NB & $Z$ & PK & PB & PB \\
\hline PB & $Z$ & PK & PB & PB & PB \\
\hline
\end{tabular}

\subsection{Metode Infrensi Min-Max}

Infrensi min-max diperoleh dari perbandingan antara nilai derajat keanggotaan error dan deltaerror. Selanjutnya, hasil dari pembandingan diambil nilai min dari derajat anggota keduanya. Perhitungan infrensi min-max pada sistem:

$$
\begin{array}{ll}
\operatorname{Error}(t) & =S P(t)-P V(t) \\
\operatorname{DeltaErTor}(t) & =\operatorname{Error}(t)-\operatorname{ErTOr}(t-1)
\end{array}
$$

\section{Keterangan :}

Error $(t) \quad$ : kesalahan pada detik(t)

Error $(t-1)$ : kesalahan sebelum detik(t-1)

$S P(t) \quad$ : Nilai yang ingin dicapai

$P V(t) \quad$ :Nilai sekarang

DeltaError : simpangan antara error pada detik(t) dan (t-1)

Inferensi Min-Max saat sample ke-31 yaitu,

$$
\begin{aligned}
\operatorname{Error}(t) & =S P(t)-P V(t) \\
\operatorname{Error}(30) & =S P(30)-P V(30) \\
& =77-76.7 \\
& =0.3 \\
& \\
\text { Error }(t) & =S P(t)-P V(t) \\
\text { Error }(31) & =S P(31)-P V(31) \\
& =78-77.9 \\
& =0.1
\end{aligned}
$$

$$
\begin{aligned}
\text { DeltaError }(t) & =\operatorname{Error}(t)-\operatorname{Error}(t-1) \\
\operatorname{DeltaError}(31) & =\operatorname{Error}(31)-\operatorname{Error}(30) \\
& =0.1-0.3 \\
& =-0.2
\end{aligned}
$$

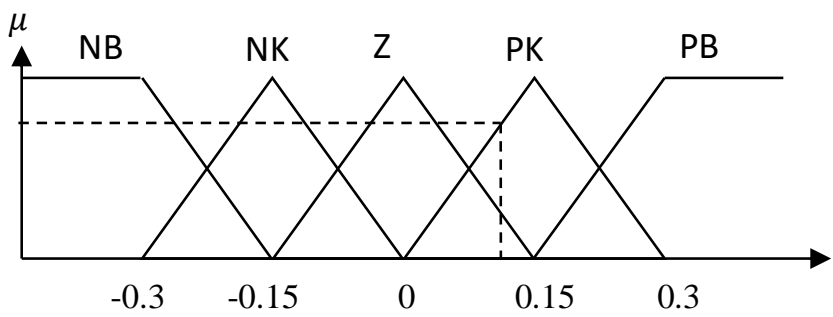

Gambar 7 Infrensi Min-Max saat semple ke-31

Nilai derajat keanggotaan Error :

$$
\begin{aligned}
& \text { Error }=0.8[\mathrm{PK}] \\
& \text { Error }=0.3[\mathrm{Z}]
\end{aligned}
$$

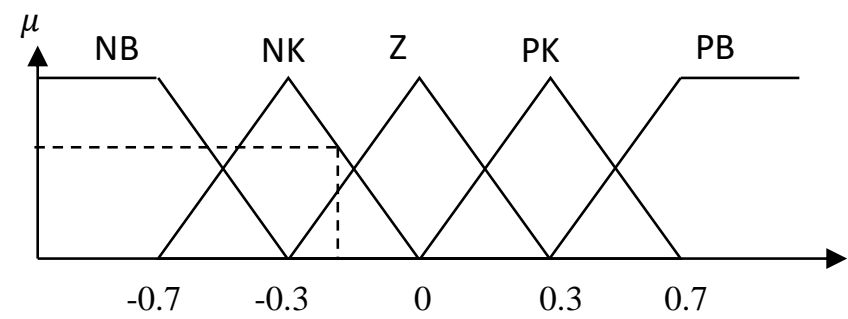

Gambar 8 Infrensi Min-Max saat semple ke-31

Nilai derajat keanggotaan DeltaError :

$$
\begin{aligned}
& \text { DeltaError }=0.6[\mathrm{NK}] \\
& \text { DeltaError }=0.4[\mathrm{Z}]
\end{aligned}
$$

Hasil :

$$
\begin{array}{ll}
\text { Error } 1=0.8[\mathrm{PK}] & ->\text { DeltaError } 1=0.6[\mathrm{NK}]=0.6[\mathrm{Z}] \\
\text { Error } 1=0.8[\mathrm{PK}] & ->\text { DeltaError } 2=0.4[\mathrm{Z}]=0.4[\mathrm{PK}] \\
\text { Error } 2=0.3[\mathrm{Z}] & ->\text { DeltaError } 1=0.6[\mathrm{NK}]=0.3[\mathrm{NK}] \\
\text { Error } 2=0.3[\mathrm{Z}] & ->\text { DeltaError } 2=0.4[\mathrm{Z}]=0.3[\mathrm{Z}]
\end{array}
$$

\subsection{Defuzzifikasi}

Defuzzifikasi adalah proses untuk mengubah keluaran fuzzy menjadi keluaran crip. Hasil defuzzifikasi inilah yang digunakan untuk mengatur besarnya sudut phasa. Metode defuzzifikasi yang digunakan adalah COA (Center of Area). Berdasarkan sampel ke-31 maka keluaran yang 
didapat sebagai berikut,

$$
\begin{aligned}
U & =\frac{\sum_{i=1}^{n} w_{i} u_{i}}{\sum_{i=1}^{n} w_{i}} \\
U & =\frac{0.6 \times Z+0.4 \times P K+0.3 \times N K}{0.6+0.4+0.3} \\
U & =\frac{0.6 \times(0)+0.4 \times(120)+0.3 \times(30)}{0.6+0.4+0.3} \\
U & =43.84
\end{aligned}
$$

Dari hasil diatas merupakan perhitungan matematis dari sistem logika fuzzy. Dimana saat sampel ke-31 output yang dihasilkan 43.84. Hasil sampel ke-31 terletak diantara Negatif Besar dan Zero. Seperti yang ditunjukan gambar 8. Dalam program hasil sampel ke-31 akan dibulatkan menjadi integer.

\section{HASIL DAN PEMBAHASAN}

Hasil penelitian ini merupakan sampel ke-31 dengan setpoint dari kelembaban udara $60 \% \mathrm{RH}$ menjadi $79 \%$ RH. Penelitian pada sampel ke-31 ini dilakukan dengan pemantauan secara berkala setiap 30 detik. Hasil respon kelembaban terhadap waktu dari sampel ke-31 ditampilkan dalam grafik seperti ditunjukan pada Gambar 11.

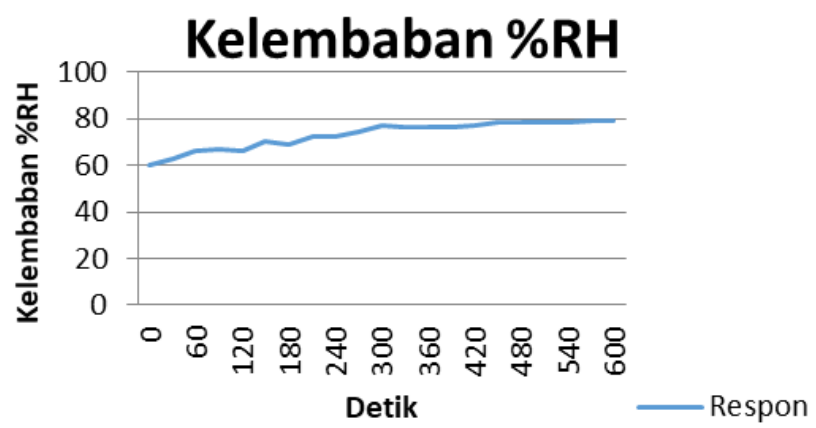

Gambar 9 Grafik Hasil respon dari pengaturan suhu dari $60 \%$ RH ke 79\% RH terhadap waktu

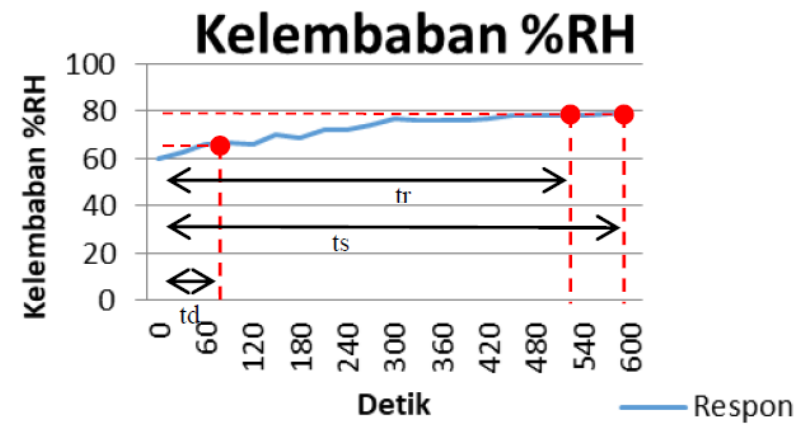

Gambar 10 Grafik Hasil respon pengujian kendali kelembaban terhadap waktu

Berdasarkan Gambar 12 maka, nilai-nilai parameter transient yang didapat seperti $t d$ (waktu tunda) merupakan keterlambatan respon, nilai $t r$ (waktu naik) merupakan nilai perpotongan respon terhadap sumbu kesetabilan pertama, nilai $t s$ (waktu tunak) merupakan waktu yang menyatakan respon telah masuk $5 \%, 2 \%$ atau $0.5 \%$ dari keadaan setabil, nilai maksimum overshoot dan nilai error steady state. Nilai-nilai yang dimaksud adalah seperti ditunjukan dalam Tabel 4.

Tabel 4 Nilai-nilai parameter transient

\begin{tabular}{|c|c|c|}
\hline No & parameter transient & $\begin{array}{c}\text { Nilai hasil } \\
\text { pengujian }\end{array}$ \\
\hline 1 & $t d$ & 60 detik \\
\hline 2 & $t r$ & 485 detik \\
\hline 3 & $t s$ & 570 detik \\
\hline 4 & $M A X$-overshoot & $0 \%$ \\
\hline 5 & Error steady state & $0.7 \%$ \\
\hline
\end{tabular}

\section{KESIMPULAN}

Berdasakan hasil dari penerapan, pengujian dan analisis pada sistem pengaturan kelembaban udara pada greenhouse menggunakan fuzzy logic controller, dapat disimpulkan bahwa pada penerapan pengendalian kelembaban udara menggunakan fuzzy untuk mencapai setpoint dari kelembaban udara $60 \%$ RH menjadi 79\% RH, dengan parameter transient yaitu waktu tunak sebesar 570 detik, waktu naik sebesar 485 detik, waktu tunda sebesar 60 detik, error steady state sebesar $0.7 \%$ dan tanpa overshoot. Pada penerapan fuzzy logic controller untuk mencapai setpoint dari kelembaban udara $60 \% \mathrm{RH}$ menjadi $79 \%$ RH membutuhkan 600 detik.

\section{REFERENSI}

[1] Dynes Rizky Navianti, I Gusti Ngurah Ray, Farida Agustini W, "Penerapan Fuzzy Inference System Pada Prediksi Curah Hujan di Surabaya Utara," J. Sains dan Seni ITS, vol. I, no. 1, p. I, 2012.

[2] D. N. Meivita, M. Rivai, and A. N. Irfansyah, "Development of an electrostatic air filtration system using fuzzy logic control," Int. J. Adv. Sci. Eng. Inf. Technol., vol. 8, no. 4, pp. 1284-1289, 2018

M. D. L. Radimas Putra, M. Rivai, and A. N. Irfansyah, "Unmanned Surface Vehicle Navigation Based on Gas Sensors and Fuzzy Logic Control to Localize Gas Source," J. Phys. Conf. Ser., vol. 1201, no. 1, 2019 
[4] S. Hadi, M. Rivai, and D. Purwanto, "Leader-Follower Formation System of Multi-Mobile Robots for Gas Source Searching," J. Phys. Conf. Ser., vol. 1201, no. 1,2019

[5] B. R. P. D. Palevi, M. Rivai, and D. Purwanto, "Fuzzy Logic-Based Wet Scrubber to Control Air Pollutant," Proc. 2019 Int. Semin. Intell. Technol. Its Appl. ISITIA 2019, no. January 2020, pp. 74-79, 2019

[6] K. Sugiarto, M. Rivai, and A. N. Irfansyah, "Control of livestock waste odors using gas sensors and fuzzy logic," Proc. 2019 Int. Conf. Inf. Commun. Technol. Syst. ICTS 2019, no. July, pp. 81-86, 2019

[7] P. Tarigan, "Sistem Pengendali Pendingin Ruangan Menggunakan Fuzzy Logic Berbasis Mikrokontroler Atmega 8535," Informasi dan Teknologi Ilmiah (INTI), vol. 1, no. 1. pp. 86-92, 2013.

[8] H. Abbas, R. Syam, and B. Jaelani, "Rancang Bangun Greenhouse Sebagai Tempat Budidaya Tanaman Menggunakan Solar Cell Sebagai Sumber Listrik," Proceeding Semin. Nas. Tah. Tek. Mesin, no. Snttm Xiv, pp. $7-$ 8, 2015.

[9] R. Kurniawan, W. Kurniawan, and R. Maulana, "Prototype Rancang Bangun Sistem Cerdas Pengatur Otomasi Suhu , Kelembaban , dan Sirkulasi Udara Pada Greenhouse Menggunakan Metode Fuzzy logic," J. Pengemb. Teknol. Inf. dan Ilmu Komput., vol. 3, no. 8, pp. 7981-7989, 2019.

[10] E. Dian, F. Prasmatiwi, and A. Suryani, "Efisiensi produksi dan analisis risiko budidaya selada keriting hijau dan selada," JIIA, vol. 5, no. 3, pp. 242-249, 2017.

[11] Y. A. Kurnia Utama, "Perbandingan Kualitas Antar Sensor Suhu dengan Menggunakan Arduino Pro Mini," e-NARODROID, vol. 2, no. 2,2016

[12] M. Rivai, Rendyansyah, and D. Purwanto, "Implementation of fuzzy logic control in robot arm for searching location of gas leak," 2015 Int. Semin. Intell. Technol. Its Appl. ISITIA 2015 - Proceeding, no. December
2016, pp. 69-74, 2015

[13] F. Matondang, R. Kusumawati, and Z. Abidin, "Fuzzy Logic Metode Mamdani Untuk Membantu Diagnosa Dini Autism Spectrum Disorder," Matics, 2012 